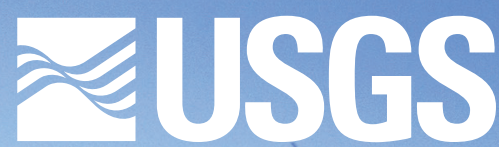

science for a changing world
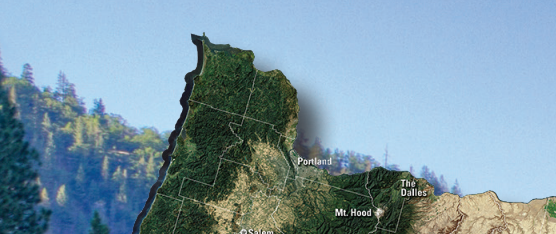

(⿻)

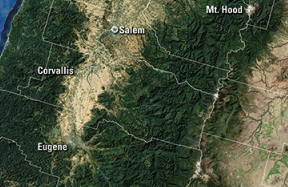

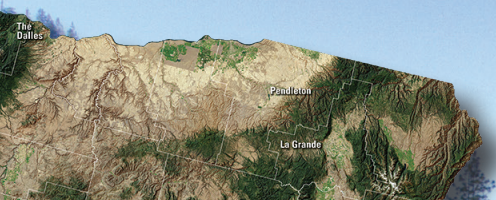

.

.
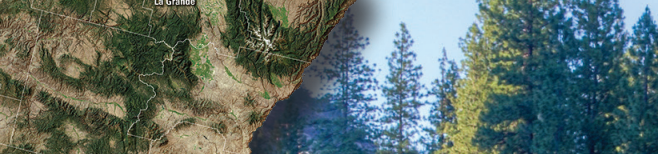

然

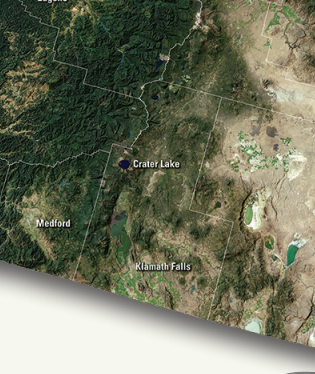

0

Oregon's landscape is as complex and diverse as it is beautiful. Mountain peaks in the Cascade Range soar higher than 10,000 feet. Crater Lake sinks to a depth of 1,943 feet, making it the deepest lake in the United States. Oregon's lands feature forests, farm fields, grasslands, ocean coastline, rivers, a semidesert, and mountain ranges that stretch across the State. A wide range of birds, animals, and fish-including 16 federally endangered species - share this space with more than 4 million people.

With Oregon's economy tied to these natural resources, industries like agriculture, timber, and fishing interlace with the well-being of wildlife and residents. Landsat data and imagery are one of many USGS tools used by State resource managers and scientists to help achieve a natural balance and provide information about forests, habitats, and much more to Oregon decision makers. This will become even more important as research indicates climate change will make extreme weather more likely, leading to the likely increase in droughts, infestation, wildfires, and other natural hazards (Jay and others, 2018).

Here are a few examples of how Landsat benefits Oregon.

\section{National Land Imaging Program Benefits-Oregon}

The U.S. Geological Survey (USGS) National Land Imaging Program provides a wide range of satellite imagery and other remotely sensed and geospatial data to Government, commercial, academic, and public users. Those users can get worldwide access to Landsat satellite data through the National Land Imaging Program-funded USGS Earth Resources Observation and Science (EROS) Center.

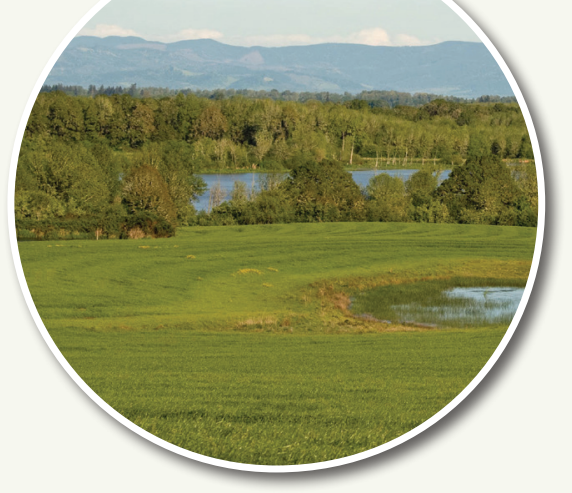

\section{Landsat Helps Characterize the Changing Landscape of the Willamette Valley}

The fertile Willamette Valley is home to much of Oregon's people and production, including a thriving wine industry and unique crops like mint and Christmas trees. Landsat's deep archive helps various agencies monitor land use and land features in the valley. Oregon State University (OSU) and U.S. Forest Service researchers applied 40 years of Landsat imagery to characterize wetlands and see where, when, and how they had changed (Fickas and others, 2016). OSU and U.S. Department of Agriculture researchers identified 13 years of agricultural crop changes across the valley with Landsat data (Strimbu and others, 2021), and the U.S. Fish and Wildlife Service has relied on Landsat-derived datasets to determine the locations of priority conservation habitats for sensitive wildlife and plants (U.S. Fish and Wildlife Service, 2017).

\section{Oregon's Willamette Valley is home to} agricultural land, grassland, forests, waterways, and wetlands, along with diverse wildlife and plant species. Image credit: George Gentry, U.S. Fish and Wildlife Service.

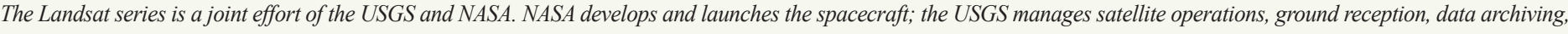
product generation, and data distribution. Funding for the National Land Imaging Program's Landsat operations and data management is provided through the USGS. 


\section{Taking the Mystery out of Irrigation}

The waters of the Upper Klamath Basin are a precious and vital resource to many Oregonians in complex and differing ways. Farmers rely on irrigation to raise cash crops like cereal grains, potatoes, and onions, as well as hay and grasses for livestock. Oregon's Native American Tribes need sufficient water in rivers to support fishing and cultural traditions. Fish species need adequate water to thrive. Detailed water use information can help the U.S. Bureau of Reclamation manage the basin's limited supply available for irrigation, especially in times of drought. Landsat has helped USGS scientists provide a key tool for the Bureau to measure


irrigation water use through evapotranspiration (ET), or the movement of water into the atmosphere via evaporation and plant transpiration.

This map of the Upper Klamath Basin shows the estimates of actual ET for June-September 2016 using Landsat data in the Operational Simplified Surface Energy Balance ET model (areas in darker blue are bodies of water). Image credit: Velpuri and others, 2020.

\section{Offering a Clearer Picture of Forests}

The Oregon Department of Forestry and the U.S. Forest Service use Landsat for monitoring and managing the effects of events such as wildfires, invasive insects, timber harvesting, and urbanization. Landsat's archive has enabled the production of maps that show changes over time in forest vegetation and habitats for species of concern, and it has helped outline the forests' carbon storage capacity. This information helps safeguard Oregon's forests for future generations of residents and wildlife.

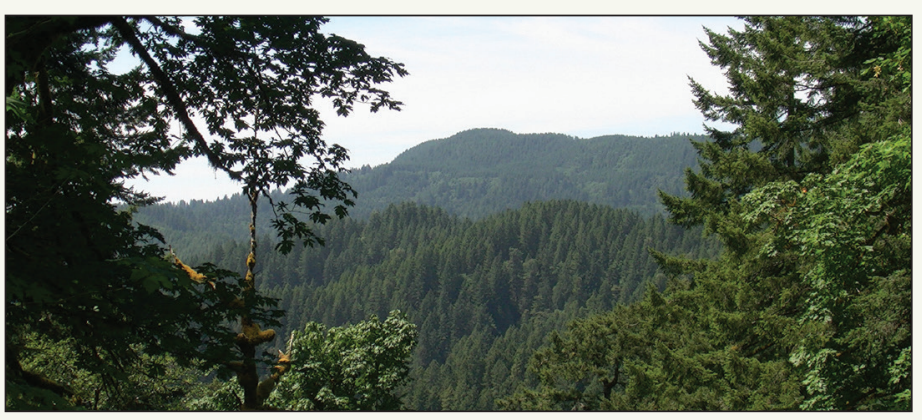

Siuslaw National Forest runs along the coast of western Oregon. Oregon has 11 national forests and 6 State forests. Photograph credit: Steven Sobieszczyk, USGS.

\section{References Cited}

Fickas, K.C., Cohen, W.B., and Yang, Z., 2016, Landsat-based monitoring of annual wetland change in the Willamette Valley of Oregon, USA from 1972 to 2012: Wetlands Ecology and Management, v. 24, p. 73-92. [Also available at https://doi.org/10.1007/s11273-015-9452-0.]

Jay, A., Reidmiller, D.R., Avery, C.W., Barrie, D., DeAngelo, B.J., Dave, A., Dzaugis, M., Kolian, M., Lewis, K.L.M., Reeves, K., and Winner, D., 2018, Overview, in Reidmiller, D.R., Avery, C.W., Easterling, D.R., Kunkel, K.E., Lewis, K.L.M., Maycock, T.K., and Stewart, B.C., eds., Impacts, risks, and adaptation in the United States: Washington, D.C., U.S. Global Change Research Program, Fourth National Climate Assessment, v. II, p. 33-71. [Also available at https://doi.org/10.7930/NCA4.2018.CH1.]

Straub, C.L., Koontz, S.R., and Loomis, J.B., 2019, Economic valuation of Landsat imagery: U.S. Geological Survey Open-File Report 2019-1112, 13 p., accessed April 2021 at https://doi.org/10.3133/ofr20191112.

Strimbu, B.M., Mueller-Warrant, G., and Trippe, K., 2021, Agricultural crop change in the Willamette Valley, Oregon, from 2004 to 2017: Data, v. 6, no. 2, 17 p. [Also available at https://doi.org/10.3390/data6020017.]

U.S. Fish and Wildlife Service, 2017, Willamette Valley Conservation Study-Strategic habitat conservation in Oregon's Willamette Valley: Portland, Oregon, U.S. Fish and Wildlife Service, 148 p. [Also available at https:// www.fws.gov/yourwillamettevalley/Conservation_Study/WVCS_Study.pdf.]

Velpuri, N.M., Senay, G.B., Schauer, M.P., Garcia, C.A., Singh, R.K., Friedrichs, M.O., Kagone, S., Haynes, J.V., and Conlon, T.D., 2020, Assessing the impact of irrigation curtailment using Landsat satellite data: A case study in the Upper Klamath Lake basin: U.S. Geological Survey data release, accessed April 2021 at https:// doi.org/10.5066/P9BC38CL.

\section{Landsat-Critical Information Infrastructure for the Nation}

Landsat is the most widely used land remote sensing data source within Federal civilian agencies. Local, State, Tribal, and Federal agencies use Landsat to monitor and forecast a wide range of land surface phenomena. Information from Landsat contributes to day-to-day decisions on land, water, and resource use that protect life and property; safeguard the environment; advance science, technology, and education; support climate change resiliency; and grow the U.S. economy. Landsat's imagery provides a landscape-level view of land surface, inland lake, and coastal processes, both natural and human-induced. Landsat enables us to better understand the scope, nature, and speed of change to the natural and built environment.

Businesses draw upon Landsat data to provide customer-specific applications to improve logistics, resource allocation, and investment decisions. Commercial space imaging firms leverage Landsat data to refine product offerings and support new information services. A 2017 USGS study determined the total annual economic benefit of Landsat data in the United States to be $\$ 2.06$ billion, far surpassing its development and operating costs (Straub and others, 2019).

Landsat 8 and Landsat 9 provide 8-day repeat coverage of the Earth's land surfaces. The National Aeronautics and Space Administration (NASA) and the USGS are currently reviewing the findings from a joint Architecture Study Team, which will inform the design and implementation approach for Landsat Next, the follow-on mission to Landsat 9. Landsat 9 and its successors are planned to provide a sustainable, space-based system to extend the 50 -year Landsat series of high-quality global land imaging measurements - the world's longest time series of the Earth's land surface.

The long-term availability of consistent and accurate Landsat data, combined with a no-cost data policy, allows users to analyze extensive geographic areas and to better understand and manage longterm trends in land surface change. New cloud computing and data analytics technologies use Landsat data in a wide range of decision-support tools for Government and industry. Much like global positioning system and weather data, Landsat data are used every day to help us better understand our dynamic planet.

For additional information on Landsat, please contact: Program Coordinator

USGS National Land Imaging Program

12201 Sunrise Valley Drive

Reston, VA 20192

703-648-5953

ISSN 2327-6916 (print) ISSN 2327-6932 (online) https://doi.org/10.3133/fs20213021 